\title{
Rights of persons with conditions associated with disability: Current legal framework
}

\author{
Graciela Moya M.D. ${ }^{a}$
}

\begin{abstract}
The objective of this review study is to promote the dissemination of the legislation in force in Argentina for the protection of the rights of persons with conditions that might cause disability. Articles of bills and laws that protect the rights of these families are reviewed, so that health care providers assisting them have better access to them. Argentina has a widerange of laws and regulations dedicated to protecting them, but they are generally not clearly recognized by citizens. The aim is to disseminate this information in the medical setting so that health care providers can help patients recognize their rights through empowerment.

Key words: children with disability, human rights, legislation, empowerment, legal aspects.
\end{abstract}

http:/ /dx.doi.org/10.5546/aap.2016.eng.355

\section{INTRODUCTION}

Knowing laws and regulations is a citizen commitment. ${ }^{1}$ Once a bill is passed by the Legislature and enacted by the Executive Power, it has a binding effect immediately after its publication in the Official Gazette. ${ }^{2}$

Our legislative system consists of several laws and regulations that protect patients' rights, and they are specifically focused on the prevention of conditions that might be associated with disabilities.

a. Institute of Bioethics, School of Medical Sciences, Pontificia Universidad Católica Argentina.

E-mail address:

Graciela Moya, M.D., gracielamoya@uca.edu.ar

Funding:

None.

Conflict of interest:

None.

Received: 11-9-2015

Accepted: 2-25-2016

\section{Situation in Argentina}

The National Survey of Persons with Disabilities (ENDI) conducted in 2002-2003 by the National Statistics and Censuses Institute of Argentina (Instituto Nacional de Estadistica $y$ Censos, INDEC) $)^{3}$ states that $7.1 \%$ of the population and $20.6 \%$ of households have, at least, a person with a disability. UNICEF Argentina, according to data obtained from the 2010 National Census of Population, Households and Housing of INDEC, reports that $6.7 \%$ of children and adolescents younger than 20 years old have some kind of permanent difficulty or limitation. ${ }^{4}$

From the ENDI 2002-2003, it stems that $14.6 \%$ of persons with disability have a Unique Certificate of Disability (CUD)..$^{5}$ Out of this percentage, approximately $22.8 \%$ are children and adolescents younger than 14 years old; that is to say that over $70 \%$ of children with disability have not requested the CUD. ${ }^{5}$

Núñez et al. ${ }^{6}$ conclude that families with persons with a disability have to deal with two situations; on the one hand, with the search for the diagnosis and treatment of the condition and, on the other hand, with overcoming bureaucratic hurdles, caused by the health care system and the society, to integrate the person with the disability and their families. These hurdles are more difficult to overcome when a person with a disability is unaware of his/her rights and is socially left aside. The search for a solution to these conflicts originates an overwhelming burden and burnout in the family, preventing them from spotting, recognizing and dealing with those needs as a family system, and consequently raising barriers to full inclusion in the society. Many families are unaware of their needs, of the information they require, and have little access to information resources. Among these needs, they do not realize they require legal information to protect their rights because they are not aware of health and pro-inclusion regulations. Families consider their link with health care providers as one of the most important ones, and claim a better health care quality, to be listened to carefully and continuously, and ask them to develop and coordinate services of information, nurturance, and emotional support. 
They perceive the medical act as fragmented in its own discipline and consider that providers, in general, are unaware of their emotional, social, spiritual or legal needs. ${ }^{6}$

To avoid this fragmentation from occurring and provide a more comprehensive care including the different models of understanding disability (from a medical, social and abilities perspective), ${ }^{7}$ physicians should integrate a transdisciplinary knowledge. In this way, providers base their care on strategies that will facilitate the detection of needs within the family system and orient them to finding a solution: taking into account family resources and looking for institutions and associations that provide useful services to families with the objective of favoring autonomy and independent development of a child with a disability.

\section{Work proposal}

The proposal of this work is based on the possibility that health care providers have a proactive approach, oriented towards strengthening families' abilities so that they recognize their needs and become aware of the solutions to them. ${ }^{8}$ This approach, known as "health empowerment", is considered a social, cultural, psychological or political process by means of which individuals and social groups are able to state their needs, describe their concerns, design strategies to participate in the decision-making process, and participate in political, social and cultural actions to cope with their needs. ${ }^{9}$ Consequently, the medical act will become a transdisciplinary knowledge if it is able to comprise, among others, the information related to legal tools currently in force, whose aim is to protect and include persons with disabilities, with their special needs and virtues, in the community life.

Hence, the objective of this study is to review articles of laws that protect the rights of persons with a disability or with conditions that might cause them so that health care providers are able to counsel the families they are taking care of.

\section{Review of the most relevant articles of the legislation currently in force}

Articles of laws and regulations directly related to health care are reviewed. Attached there is a list of websites where the full text of an Act or Law can be found and a table with other related national acts and bills (Table 1).

1. Act 22431. Comprehensive system of protection to the disabled ${ }^{10}$ (March, 1981). This Act provides for a system of comprehensive protection for persons with disabilities, with the aim of ensuring that they receive medical care, education, and social security. It also grants exemptions and incentives in order to give them opportunities, through their own efforts, to fulfill a role in society that is equivalent to that of citizens without disabilities. In order for these rights to be recognized, the $\mathrm{CUD}^{11}$ is instituted to provide certain benefits to the disabled at a national level. ${ }^{12}$

2. Act 23661. National system of health insurance ${ }^{13}$ (January, 1989). This Act establishes -in article 28- that rehabilitation services should be provided to disabled persons and coverage for medicines to persons requiring them should be ensured.

3. Act 23849. International convention on the rights of the child ${ }^{14}$ (October, 1990 reservations made). The ratification of Argentina considers a comprehensive protection of the child from the time of conception and makes a special reference to children with conditions that result in disabilities. It defines: "child refers to all human beings from the time of conception until 18 years of age"; it gets back to the Declaration of the Rights of the Child (1954): "the child, by reason of his physical and mental immaturity, needs special safeguards and care, including appropriate legal protection, before as well as after birth." In article 6, States Parties recognize "that every child has the inherent right to life. States Parties shall ensure to the maximum extent possible the survival and development of the child"; and, in article 23, it makes special reference to the needs, rights, and integration of children with conditions resulting in disability: "the mentally or physically disabled child should enjoy a full and decent life, in conditions which ensure dignity, promote self-reliance and facilitate the child's active participation in the community." In article 24, it underscores "the right of the child to the enjoyment of the highest attainable standard of health and to facilities for the treatment of illness and rehabilitation of health." It makes special reference to the prenatal and maternity stages, since, in this same article it states: "To ensure appropriate antenatal and postnatal health care for mothers."

4. Act 24716. Leave for mothers of children with Down's syndrome ${ }^{15}$ (October, 1996). This Act establishes a special leave for working 
mothers, with employee status, whose child is born with the diagnosis of Down's syndrome. It stipulates that mothers are "entitled to six months of unpaid maternity leave as of the last date of paid maternity leave," at which time "they will start receiving a family allowance." It keeps the spirit of mother and child safeguarding, especially in the case of diseases that might require greater maternal care without affecting their work.

TABLE 1. National laws related to the protection of health rights ${ }^{27}$

\begin{tabular}{|c|c|c|}
\hline $\begin{array}{l}\text { National } \\
\text { laws }\end{array}$ & Title & Benefits \\
\hline Act 18910 & Disability pension. & Request a non-contributory pension for disability. \\
\hline Act 19279 & Cars for physically disabled persons. & $\begin{array}{l}\text { Purchase a national vehicle with a VAT relief scheme or } \\
\text { suspension of duties on imported vehicles. International } \\
\text { symbol of free transit and parking. }\end{array}$ \\
\hline Act 22431 & Comprehensive protection system for disabled persons. & Please, refer to the text. \\
\hline Act 22909 & $\begin{array}{l}\text { General immunization schemes against vaccine- } \\
\text { preventable diseases. }\end{array}$ & National mandatory immunization scheme. \\
\hline Act 23660 & $\begin{array}{l}\text { Health care system act. Entitled beneficiaries of the } \\
\text { health care system. }\end{array}$ & $\begin{array}{l}\text { Medical services and medications should be provided } \\
\text { free of charge to persons with disabilities. }\end{array}$ \\
\hline Act 23661 & National health insurance act. & Please, refer to the text. \\
\hline Act 23753 & Problems and prevention of diabetes. & $\begin{array}{l}100 \% \text { coverage of medicines and diagnostic reagents } \\
\text { for self-monitoring of blood glucose for patients with } \\
\text { diabetes. }\end{array}$ \\
\hline Act 23798 & $\begin{array}{l}\text { Fight against acquired immune deficiency syndrome } \\
\text { (AIDS). }\end{array}$ & $\begin{array}{l}\text { Detection, investigation, diagnosis, and treatment of } \\
\text { AIDS. }\end{array}$ \\
\hline Act 24195 & Federal education act. & $\begin{array}{l}\text { Integration of persons with special needs through the full } \\
\text { development of their skills. }\end{array}$ \\
\hline Act 24314 & Accessibility for persons with reduced mobility. & It claims full physical accessibility. \\
\hline Act 24714 & Family allowance scheme. & $\begin{array}{l}\text { Family allowance for families who have a child of any } \\
\text { age, with disabilities. }\end{array}$ \\
\hline Act 24754 & Prepaid medical services. Coverage. Services. & $\begin{array}{l}\text { Companies should cover "mandatory benefits" arranged } \\
\text { by health insurance. }\end{array}$ \\
\hline Act 24901 & $\begin{array}{l}\text { System of basic services for comprehensive habilitation } \\
\text { and rehabilitation for persons with disabilities. }\end{array}$ & Please, refer to the text. \\
\hline Act 25280 & $\begin{array}{l}\text { Approval of the Inter-American convention against all } \\
\text { forms of discrimination and intolerance for persons } \\
\text { with disabilities. }\end{array}$ & $\begin{array}{l}\text { Eliminates all forms of discrimination against persons } \\
\text { with disabilities; fosters their full integration into society. }\end{array}$ \\
\hline Act 25404 & $\begin{array}{l}\text { Adoption of safeguard measures for persons with } \\
\text { epilepsy. }\end{array}$ & Please, refer to the text. \\
\hline Act 25415 & $\begin{array}{l}\text { National program for the early detection and care of } \\
\text { hearing impairment. }\end{array}$ & Please, refer to the text. \\
\hline Act 25421 & Primary mental health care program. & Right to receiving primary health care services. \\
\hline Act 26279 & $\begin{array}{l}\text { Procedure for the detection and treatment of certain } \\
\text { conditions in newborn infants. }\end{array}$ & Please, refer to the text. \\
\hline Act 26378 & $\begin{array}{l}\text { Approval of the convention on the rights of persons } \\
\text { with disabilities and its optional protocol. }\end{array}$ & Please, refer to the text. \\
\hline Act 26396 & Prevention and management of eating disorders. & $\begin{array}{l}\text { It promotes, especially among children and adolescents, } \\
\text { healthy eating habits. }\end{array}$ \\
\hline Act 26588 & Celiac disease act. & Please, refer to the text. \\
\hline Act 26657 & Right to mental health safeguard. & Mental health safeguarding for all persons. \\
\hline Act 26796 & $\begin{array}{l}\text { Mother and child plan, Calmette-Guerin } \\
\text { Bacillus (CGB) vaccine for children. }\end{array}$ & $\begin{array}{l}\text { It introduces CGB vaccination in the mother and child } \\
\text { plan for the pediatric population at a national level. }\end{array}$ \\
\hline
\end{tabular}


5. Act 24901. System of basic services for comprehensive habilitation and rehabilitation for persons with disabilities ${ }^{16}$ (December, 1997). It includes "prevention, assistance, promotion and protection actions" for persons with disabilities, "with a view to providing comprehensive coverage for their needs and requirements." There are two chapters particularly interesting. Article 14, related to preventive services: "Adequate check-ups, care and prevention services will be guaranteed to the mother and the child as of the time of conception for their optimal physical growth, and psychological and social development." It comprehensively interprets a person as of the time of conception and provides for prenatal studies and treatments, particularly if there are risk factors. "Additionally, if risk factors are present, efforts should be focused on check-ups, care, treatment and the necessary complementary examinations to prevent a condition or to detect it early enough to prevent it from becoming a serious condition. Once the condition that might determine disability in the mother or the child is detected, preventive or early treatments are recommended..." In chapter VII, other situations are taken into account: economic aspects, insertion in society and the workplace, access to different health care services, drugs or diet therapy products, or psychiatric care (articles 33-38). Article 39 provides a comprehensive approach to the family of a person with disabilities, particularly in genetic-hereditary diseases: "a) Care provided by specialists who do not belong to the body of providers and who should necessarily participate given the specific characteristics of the condition..."; "b) Those diagnostic tests and check-ups that are not included within the services provided by entities required to do so by the present Act..."; “c) Diagnosis, orientation and preventive counseling to members of the family group of patients with genetic-hereditary conditions."

These subparagraphs can be adopted in the case of rare disorders causing disabilities.

6. Act 25404. Special measures for persons with epilepsy $^{17}$ (March, 2001). It makes reference to the integration and non-discrimination of persons with epilepsy and to the inclusion of medical and health services to the Mandatory Medical Program (PMO). Persons who are not covered by social programs or who do not have resources are entitled to: “h) Receiving the required medication for free" through the Ministry of Health as the enforcement authority.

7. Act 25415. Early detection and care of hearing impairment $^{18}$ (April, 2001). The objective is to detect hearing impairment at an early stage, before three months of life, and to provide hearing aids and the phonoaudiological treatment services included in the Mandatory Medical Program.

8. Act 26279. Procedure for the detection and treatment of certain conditions in newborn infants ${ }^{19}$ (September, 2007). It makes reference to the early detection of those disorders and conditions that can be susceptible to treatment. Article 1 establishes that: "Upon birth, all newborn infants must be screened, for purposes of detection and treatment, for phenylketonuria, neonatal hypothyroidism, cystic fibrosis, galactosemia, congenital adrenal hyperplasia, biotinidase deficiency, retinopathy of prematurity, Chagas disease, and syphilis." Article 2 provides for "mandatory screening of other genetic metabolic and/or congenital disorders that are not evident at the time of birth...." It not only considers the diagnosis, prescribed diet or drug treatment but also the dissemination, research, epidemiological and training objectives as well as the integration with non-governmental organizations (NGOs).

9. Act 26378. It adopts the Convention on the Rights of Persons with Disabilities ${ }^{20}$ (June, 2008) having constitutional rank..$^{21}$ The aim is "to promote, safeguard and ensure that persons with disabilities are able to fully enjoy all human rights and fundamental freedoms, and to promote respect for their intrinsic dignity." The term "persons with disabilities" includes "persons who have longterm physical, mental, intellectual or sensory impairments which in interaction with various barriers may hinder their full and effective participation in society on an equal basis with others." It promotes the "social model of disability."

10. Act 26588. Celiac disease care, research, treatment ${ }^{22}$ (December, 2009). It includes the characteristics, classification, registry and production of gluten free food made of wheat, oats, barley, rye (GF) and the "medical coverage of persons with celiac disease...", "...the detection, diagnosis, check-up and treatment, that include gluten free flours and 
premixes..." having or not having medical coverage. Given that diet therapy is expensive, it establishes a fixed monthly reimbursement amount by the health insurance system.

11. Act 26682. Regulatory framework for prepaid medical services ${ }^{23}$ (May, 2011, Decree 1993/2011). Article 7 establishes that it is mandatory to, at least, cover what is determined in the "Mandatory Medical Program in force as per Resolution of the National Ministry of Health and the System of basic services for persons with disabilities, included in Act 24901 and amendments." In article 10, it clarifies that: "these programs should not include waiting periods for all those benefits delivered within the Mandatory Medical Program". Article 20 adds that the coverage should pay services performed and billed at hospitals "from the national, provincial or municipal sectors, and those of the social security."

12. Act 26689. Comprehensive health care of persons with rare diseases ${ }^{24}$ (July, 2011, Decree 794/15). "Its aim is to provide comprehensive health care for persons with rare diseases and to improve their quality of life as well as their families'." It defines "rare diseases as those whose prevalence in the population is equal to or lower than one in every two thousand (1 in 2000) individuals." It promotes comprehensive care of persons with rare diseases through "early detection, diagnosis, treatment, and recovery..." and creates an Honorary Council for the approach and treatment of these conditions and a National Program of Rare Diseases to identify and strengthen reference centers; to disseminate available information; train health care team members; and to promote the development and production of medicines and medical devices.

13. Act 27043 . Comprehensive and interdisciplinary approach to persons with autistic spectrum disorders (ASDs) ${ }^{25}$ (December, 2014). It underscores two important points: "to ensure clinical and epidemiological investigation, early detection, diagnosis and treatment, dissemination and access to intervention services to ASDs" and introduces, into the Mandatory Medical Program, screening procedures, early detection and diagnosis, and the necessary services to the comprehensive and interdisciplinary approach to those persons with ASDs, updated in line with the latest scientific advances.
14. Mandatory Medical Program, dependent on the Superintendence of Public Health ${ }^{26}$ (Resolution 201/2002). The Mandatory Medical Program establishes that health care plans and insurance companies should guarantee the delivery of essential basic benefits through their own or third-party providers. The list of mandatory services to be provided is described in Annex II. A treatment formulary with a listing of active ingredients that should be guaranteed to the beneficiary, as well as the price list, is included in Annex III.

\section{CONCLUSIONS}

There are many laws protecting the rights of families and of patients with diseases that cause disabilities. By being aware of our legislations, health care providers can contribute to empowerment for the health of their patients. This also requires greater commitment, participation, and responsibility of persons, both of health care providers as well as families, that will enable persons with disabilities to become aware of their needs and make health care decisions freely.

The concept of empowerment for health comes from an anthropological vision of man built on the respect for human life, the dignity, variance and commitment of every person to continuously participate in contributing to the common good and that of the human person.

\section{REFERENCES}

1. Ley 26994. Código Civil y Comercial. Título Preliminar. Capítulo 2. Artículo $8 .^{\circ}$. Principio de inexcusabilidad. La ignorancia de las leyes no sirve de excusa para su cumplimiento, si la excepción no está autorizada por el ordenamiento jurídico. Buenos Aires, Argentina, 7 de octubre de 2014. [Accessed on: November $\left.9^{\text {th. }}, 2015\right]$ ]. Availableat:http:/ / www.infoleg.gob.ar/infolegInternet/ anexos /235000-239999/235975/texact.htm\#2.

2. Ley 26994. Código Civil y Comercial. Título Preliminar. Capítulo 2. Artículo 5. ${ }^{\circ}$ Vigencia. Las leyes rigen después del octavo día de su publicación oficial, o desde el día que ellas determinen. Buenos Aires, Argentina, 7 de octubre de 2014. [Accessed on: November 9 $\left.{ }^{\text {th. }}, 2015\right]$. Available athttp: / /www.infoleg.gob.ar/infolegInternet/ anexos /235000-239999/235975/texact.htm\#2.

3. INDEC Direcciones Provinciales de Estadísticas. Encuesta Nacional de Personas con Discapacidad. [Accessed on: June $\left.12^{\text {th }}, 2015\right]$. Availableat: http:/ / www.indec.gov.ar/micro_ sitios/webcenso/ENDI_NUEVA/index_endi.asp.

4. UNICEFArgentina. Datos sobre Infancia en Argentina. 2015. [Accessed on: Friday, June 12, 2015]. Available at: http:/ / www.unicef.org/argentina/spanish/overview_11124. htm.

5. NDECECMI.Censo2001-EncuestaNacionalComplementaria de Personas con Discapacidad. [Accessed on: June 12 $2^{\text {th. }}$, 2015]. Available at: http://www.indec.gov.ar/micro_ 
sitios/webcenso/ENDI_NUEVA/ampliada_lista_total. asp?Cap $=13 \&$ Apertu $=0$.

6. Pantano L,Núñez B, Arenaza A. ¿Quénecesitanlas familias de personas con discapacidad? Investigación, reflexiones y propuestas. Lugar Editorial: Buenos Aires; 2012.

7. Dunn M. Discourse of disability and clinical ethics support. Clinical Ethic 2011;6:32-8.

8. Moya G. La aplicación del principio de subsidiariedad en el empoderamiento de los pacientes para el cuidado de la salud: el caso de las enfermedades raras en Argentina. Acta Bioeth 2012;18(2):181-8.

9. OMS. Promoción de la Salud, Glosario. Geneva, 1998. [Accessed on: September 15 $\left.{ }^{\text {th. }}, 2015\right]$. Available at: http:// www.bvs.org.ar/pdf/glosario_sp.pdf..

10. Ley $\mathrm{N}^{\circ}$ 22431. Sistema de protección integral de los discapacitados. Buenos Aires, Argentina, 16 de marzo de 1981. [Accessed on: October 10 th. 2015]. Available at: http:/ /infoleg.mecon.gov.ar/infolegInternet/ anexos /20000-24999/20620/texact.htm.

11. Argentina. Ministerio de Salud. Servicio Nacional de Rehabilitación. Certificado Único de Discapacidad. [Accessed on: February 1 ${ }^{\text {st. }}$,2016]. Available at: http://www. snr.gob.ar/cud/.

12. Argentina. Superintendencia de Servicios de Salud. Resolución 1511/2012. Créase el Procedimiento para Autorización de Reintegros del Sistema de Tutelaje de Tecnologías Sanitarias Emergentes. Resolución N. ${ }^{\circ}$ 621/2006. Anexo II. Boletín Oficial 32536. [Accessed on: February $15^{\text {th }}$, 2016]. Available at: http://www.sssalud. gov.ar/novedades/archivos/documentos/2012120501N. pdf.

13. Ley 23661. Sistema Nacional del Seguro de Salud. Buenos Aires, Argentina, 5 de enero de 1989. [Accessed on: October 10 $0^{\text {th }}$, 2015]. Available at: infoleg.mecon.gov.ar/ infolegInternet/anexos/0-4999/63/norma.htm.

14. Ley 23849. Convención sobre los Derechos del Niño Adoptada por la Asamblea General de Las Naciones Unidas, en Nueva York el 20/11/89 - Aprobación. Buenos Aires, Argentina, 16 de octubre de 1990. [Accessed on: October 10 $0^{\text {th. }}$ 2015]. Available at: http://www.gob.gba.gov.ar/ legislacion/legislacion/1-23849.html.

15. Ley 24716. Establécese para la madre trabajadora en relación de dependencia una licencia especial, a consecuencia del nacimiento de un hijo con síndrome de Down. Buenos Aires, Argentina, 2 de octubre de 1996. [Accessed on: October 13 $\left.3^{\text {th. }}, 2015\right]$. Available at: http://infoleg.mecon.gov.ar/ infolegInternet/anexos/35000-39999/39995/norma.htm.

16. Ley 24901. Sistema de prestaciones básicas en habilitación y rehabilitación integral a favor de las personas con discapacidad. Buenos Aires, Argentina, 2 de diciembre de 1997. [Accessed on: October 13 $\left.{ }^{\text {th. }}, 2015\right]$. Availableat:http://www.infoleg.gov.ar/infolegInternet/ anexos/45000-49999/47677/norma.htm.

17. Ley 25404. Medidas especiales para personas que sufran epilepsia. Buenos Aires, Argentina, 28 de marzo de 2001. [Accessed on: October 15 $\left.5^{\text {th }}, 2015\right]$. Available at: http:// www.mapalegislativo.org.ar/index.php/legislacion/ por-territorio/nacion/239-salud-publica/592-ley-25404especiales-de-proteccion-para-las-personas-que-padecenepilepsia.
18. Ley 25415. Creación del programa nacional de detección temprana y atención de la hipoacusia. Buenos aires, Argentina, 3 de mayo de 2001. [Accessed on: October $13^{\text {th. }}$, 2015]. Available at: http:/ / www.integrando.org.ar/ juridico/salud_25415.htm.

19. Ley 26279. Régimen parala detección y posterior tratamiento de determinadas patologías en el recién nacido. Alcances. Prestaciones obligatorias. Constitución de una Comisión Interdisciplinaria de Especialistas en Pesquisa Neonatal. Propósito. Funciones del Ministerio de Salud. Buenos Aires, Argentina, 4 de septiembre de 2007. [Accessed on: October 15 $\left.{ }^{\text {th }}, 2015\right]$. Available at: http://infoleg.gov.ar/ infolegInternet/anexos/130000-134999/131902/norma. htm.

20. Ley 26378. Apruébase la Convención sobre los Derechos de las Personas con Discapacidad y su protocolo facultativo, aprobados mediante resolución de la Asamblea General de las Naciones Unidas del 13 de diciembre de 2006. Buenos Aires, Argentina, 6 dejunio de 2008. [Accessed on: February $1^{\text {st. }}$ 2016]. Available at: http://www.infoleg.gov.ar/ infolegInternet/anexos/140000-144999/141317/norma. htm.

21. Ley27044. Otórgasejerarquía constitucionala la Convención sobre los Derechos de las Personas con Discapacidad. Buenos Aires, Argentina, 11 de diciembre de2014. [Accessed on: February 21 ${ }^{\text {st. }}$,2016]. Available at: http:/ / www.infoleg. gob.ar/infolegInternet/anexos/235000-239999/239860/ norma.htm.

22. Ley 26588. Declárase de interés nacional la atención médica, la investigación clínica y epidemiológica, la capacitación profesional en la detección temprana, diagnóstico y tratamiento de la enfermedad celíaca. Buenos Aires, Argentina, 29 de diciembre de 2009. [Accessed on: October 22nd. 2015]. Available at: http://www.infoleg.gov.ar/ infolegInternet/anexos/160000-164999/162428/norma. htm.

23. Ley 26682. Marco Regulatorio de Medicina Prepaga. Buenos Aires, Argentina, 26 de mayo de 2011. [Accessed on: October $\left.3^{\text {rd. }}, 2015\right]$. Available at: http: / /www.infoleg. gov.ar/infolegInternet/anexos/180000-184999/182180/ norma.htm.

24. Ley 26689. Promuévese el cuidado integral de la salud de las personas con Enfermedades Poco Frecuentes. Buenos Aires, Argentina, 29 de julio de 2011. [Accessed on: September 12 ${ }^{\text {th. }}$, 2015]. Available at: http://infoleg.gob.ar/infolegInternet/ anexos/185000-189999/185077/norma.htm.

25. Ley 27043. Abordaje integral e interdisciplinario de las personas que presentan Trastornos del Espectro Autista (TEA). Declaración. Buenos Aires, Argentina, 7 de enero de 2015. [Accessed on: September 22 $\left.{ }^{\text {nd. }}, 2015\right]$. Available at: http:/ /www.ciudadyderechos.org.ar/convenios_l. php?id=319\&id2=367\&id3=9997.

26. Superintendencia de Servicios de Salud. Ministerio de Salud. Programa Médico Obligatorio (PMO). Resolución 201/2002. [Accessed on: September 2nd, 2015]. Available at:http:/ / www.sssalud.gov.ar/index/index.php?cat=be neficiarios\&opc=res_201.

27. Argentina. Ministerio de Salud. Legislación en salud de la República Argentina. [Accessed on: October $3^{\text {rd. }}$, 2015]. Available at: http://leg.msal.gov.ar/index2.htm 